\title{
FORMATION LEVELS OF SOCIOCULTURAL COMPETENCE OF THE FUTURE PHILOLOGISTS (ON THE EXAMPLE OF STUDENTS OF THE FACULTY OF FOREIGN LANGUAGES)
}

\author{
Olena Sali \\ Lecturer at the Department of English and Translation, \\ Izmail State Humanitarian University, Ukraine \\ e-mail: lenasali2002@gmail.com,orcid.org/0000-0003-4818-5895
}

\section{Summary}

The article considers the issue of sociocultural competence of a future teacher-philologists. Today, in connection with the educational paradigm, that is changing, and the shift in emphasis in the educational process to self-educational activities, an integral part of the professional competence of young specialists is the formation of their sociocultural competence. It is determined that students do not have theoretical and practical knowledge on the implementation and formation of sociocultural competence. The article analyzes the concepts of levels and grading. The main criteria of the component composition of sociocultural competence are highlighted. The essence of the cognitive theory proposed by D. Hirsch is revealed, which emphasizes the intellectual level of students.

The author notes that with the help of regional, cultural and sociolinguistic materials, students are introduced to the culture and realities of the countries whose language is being studied, their horizons are expanded, their communication and life experience is enriched. In addition, the ability and willingness to use a foreign language in real communication develops; the ability to represent your own country, its culture in the context of intercultural communication is formed. Learning is provided with a modern sound, focused on mutual understanding, tolerance for differences between people, joint solution of important universal human problems, cooperation and interaction, including using a foreign language.

Keywords: dialogue of cultures, sociocultural competence of a future teacher, graduation, mediator of cultures, activity criterion, cognitive theory.

DOI: https://doi.org/10.23856/4020

\section{Introduction}

The socio-economic and political conditions of the development of modern Ukrainian society have created a basis for openness in international relations and influenced the educational policy in general and the study of foreign languages in particular. The peculiarity of today's period requires understanding of the global problem, which is aimed at teaching foreign language as a means of intercultural communication. Numerous EU, Council of Europe and UNESCO projects have laid down the principles of "multilingualism", and "multiculturalism", proclaimed as paramount to national education systems. Continuously expanding contacts, mobility of the population, and especially of young people studying in different countries, implies not only the elimination of conflicts, but also the understanding of the specifics of intercultural communication in a changing world.

This situation requires that the parties in contact, in addition to language skills, have knowledge of the culture, sociocultural features of the development of a country. Previously, 
the attention of researchers was mainly focused on the development of skills within the framework of communicative competence, nowadays foreign language is also considered as a means of gaining the sociocultural experience of representatives of other linguistic and cultural communities. As the practice of teaching a foreign language shows, interest in a foreign language culture is explained by the urgent need for successful communication, which cannot be realized without taking into account the culture in the structure and content of communication as a determining condition for adapting a person to new living conditions. Indeed, in real communication, language is not the only tool for understanding. Representations of cultural information, rules and norms of behavior in a foreign language environment, studying the value orientations of representatives of another culture are very important. In today's world, the problem of mutual understanding between different people is most urgent because the conflict of cultures, caused by differences in historical, political and social development, can lead to distortions in understanding, as well as mistakes and social conflicts.

The purpose of the article is to determine the main levels and criteria of each of them in the process of formation of sociocultural competence of future teachers of philological specialties. The main tasks of the article:

- To define the essence of the concept sociocultural competence and its component composition.

- To identify the basic requirements for the levels of socio-cultural competence.

- To analyze the levels of sociocultural competence of students of the Faculty of Foreign Languages.

\section{The analysis of recent research}

In modern science, the basic provisions that form the methodological basis for the development of conceptual provisions that substantiate the effectiveness of pedagogical conditions for the formation of sociocultural competence of students - future philologists in the teaching of a foreign language are insufficiently developed.

The competence approach was studied by A. Khutorsky, and does not imply the acquisition of the student's individual knowledge and skills, but mastering them in the complex. As a result, the system of teaching methods is more or less different. The selection and design of these methods is based on the structure of relevant competences and functions that they perform in education (Khutorsky, 2003: 61).

Let us turn to the notion of sociocultural competence, which is the core of our study. It is a collection of certain knowledge, skills, qualities and abilities that are formed in the process of language preparation for intercultural communication. The emergence of the term "sociocultural competence" in the Ukrainian methodology of teaching foreign languages is linked to the activities of the international organization "Council of Europe for Cultural Cooperation", especially the works of Jan van Eck and John Trim. According to these documents, sociocultural competence is one of the components of communicative competence, understood as the ability to adequately interact in everyday life situations, to establish and maintain social contacts through a foreign language (Latukhina, 2014: 726).

To understand the investigated phenomenon, all scientists approach to it differently. According to V. Safonova, the formation of sociocultural competence plays an important role for the development of the student's personality. According to this approach, a student who has a developed sociocultural competence must not only have knowledge and skills, but also understand different cultures and correlate with them the communicative norms of communication. 
In addition, it should adequately interpret cultural phenomena and facts and use these "benchmarks to select interaction strategies for solving personally and professionally significant problems in different types of contemporary intercultural communication" (Safonova, 1991: 175).

Thus, N. Poselska defines sociocultural competence as an integrative property of a person, characterizing her theoretical and practical readiness for sociocultural activity (Poselska, 2012: 269).

Formation of sociocultural competence in the process of teaching a foreign language is considered by the author P. Sysoev, who understands under sociocultural competence the level of knowledge of the sociocultural context of the use of a foreign language, as well as the experience of communicating and using the language in different sociocultural situations. In his definition, he emphasizes the three-level's structure of sociocultural competence: knowledge, experience of communication and experience of language use (Sysoev, 2001: 15). This indicates that, at a minimum, the theoretical knowledge acquired must be "fixed" in foreign language lessons in the course of performing linguistic thematic exercises.

The questions of formation the research work of future philologists, introduction of social innovations in the educational process of educational institutions were discussed by M. Knyazyan, who claimed that it is modern teaching technologies that motivate students to productive work (Knyazyan, Muschinskaya, 2019). Innovations such as project technology, modeling, research and creative activity are considered by the authors as the most important social and pedagogical innovations for the formation and development of sociocultural competence (Knyazyan, Khromchenko, 2019).

The researcher D. Deardorf, in his work "Identifying and assessing intercultural competence as a student outcome of internationalization", identified the essence of the concept of intercultural competence, and determined that a combination of quantitative and qualitative methods, including interviews, observations and judgments on their own opinions is better for the effective formation of this competence (Deardorff, 2006).

However, the issue of diagnosing and forming the sociocultural competence of future teacher-philologists needs more thorough coverage.

\section{Theoretical foundations of formation of sociocultural competence}

At the present stage of formation sociocultural competence, especially when learning a foreign language, occupies a special place in the vocational education system, arouses the interest of many domestic and foreign scholars, because the high level of foreign language literacy of future philologists enhances the competitiveness of the country and the ability to transform the country.

When studying the issues of control in the theory and practice of learning foreign languages actively use the concept of level or graduation. Its essence is that when students master sociocultural competence, they master its elements gradually, improving their qualitative characteristics throughout the process of learning a foreign language. This led to the need to identify the control points of this process - discrete, relatively complete stages of formation and development of a number of characteristics and properties of the object, which differ in achieving them previously set value. The aggregate of these values, being the result of passing a certain checkpoint, forms a level that is defined as the degree of development of the characteristics to be diagnosed.

The process of isolation and distribution of levels is called graduation. The content and characteristics of the interconnection of components of sociocultural competence of the 
philologists allowed to define it as an integrative, relatively stable, personal formation, characterized by:

- the connection of the student - the future teacher-philologist - with the system of universal values, including knowledge about the values of native and foreign language cultures;

- ability to identify cultural values by observing and interacting with other cultures; apply the knowledge outlined in the practice of communication in order to achieve mutual understanding based on the creation of common meaning; to construct their own verbal and non-verbal behavior in accordance with the norms of the language culture being studied;

- empathy - the desire and willingness to perceive the "other" as equal, tolerance, adaptation to the phenomena of a foreign language culture.

The structural composition of sociocultural competence determined the choice of its criteria. We define the criterion as "the attribute on which the assessment is made, the means of verification, the measure of assessment. In the theory of cognition, it is a sign of truth or error of position" (Philosophical, 2003: 226).

As indicators of the cognitive component of the sociocultural competence of students future teachers of philology is the completeness and systematic knowledge of universal cultural values, as well as the values of native and foreign languages.

The forming of students' sociocultural competence involves creating in their minds the mental (psychic) equivalent of the system under study, as well as the image of the world specific to a given foreign language culture and the foreign language that serves it.

The cognitive theory offers great opportunities for developing students' sociocultural competence. This theory, which is aimed at developing students' intelligence and related to the knowledge of the second cultural reality, is reflected in the methodological concept of "knowledge of the world", proposed by Professor of English Philology D. Hirsch (1987), who, while developing the theory of "cultural literacy", emphasizes on the intellectual level of training. For the researcher, literacy involves mastering the concept of all civilization in a given culture, which can be formed in a humanitarian education setting (Riske, 2000: 11).

According to the program requirements to the level of sociocultural competence of students, they must acquire knowledge of information culture, knowledge of artistic values of culture, the basics of behavioral culture adopted in the environment of native speakers. What is fundamentally important here is that culture should be studied not just in the form of some individually existing products of intellectual labor (works of art, books, historical monuments, etc.), but also as a living activity of people in the system of uniting their social connections. As the main we highlight the following sociocultural knowledge: in the field of geography, history, literature, art, economics, politics, possessed by a typical educated native speaker of the language; systems of measures taken in the linguistic and cultural community under study; culturally oriented vocabulary and phraseology; politically correct vocabulary; precedent texts possessed by a typical enlightened native speaker of the language being studied; national psychological characteristics of representatives of a certain linguocultural community; national-specific features of verbal and non-verbal communicative behavior of members of this community; national-specific features of domestic behavior of its representatives; national-social symbolism, including national-specific symbolism of numbers, shades of colors, elements of clothing, jewelry, gifts, omens and prejudices. Sociocultural norms of behavior and customs, as well as social conventions and rituals determine the non-verbal (Non-linguistic) behavior of participants in communication. Sociocultural competence includes the following aspects of non-verbal behavior and customs: Body language - (handshake, touch, hug, kiss, gesture, facial expressions, eye language, communication distance, postures, rules of politeness); Visiting 
rituals (time of arrival / departure, gifts, clothes, treats, conversation, compliments, farewell); Eating and drinking rituals. Sociocultural competence is also covered by the Politeness conventions, which are based on generally accepted rules of conduct, such as in the UK, as an expression of respect and concern for a communication partner (Babushkina, 2012: 16).

Particular attention should be paid to such an aspect of sociocultural competence as knowledge of the cultural heritage of the UK, especially its literature, which integrates both language and culture of the country. It is not possible to cover this topic widely in the study of a foreign language. However, there is a layer of culture without which its carriers cannot be understood. Such realities include: folklore as a reflection of the collective consciousness of the people; major historical figures who lived at a turning point, key periods in history; works of prose writers, poets, and philosophers, who made a significant impact on the development of the mentality of native speakers. This contributes to the development of students' analytical skills, the ability to social adaptation on the basis of a more adequate understanding of their country and their culture.

An indicator of the activity-practical component of the sociocultural competence of the students of the language faculty is the degree of forming the ability to distinguish cultural values, as well as to apply the above knowledge in the practice of communication in the framework of "dialogue of cultures". In accordance with the program requirements for the level of sociocultural competence, students must develop the skills necessary for communication in a foreign language with representatives of other cultures. The subject aspect of the activity criterion is the following skills:

- ability to use discursively the above knowledge; ability to find similarities and differences in the history, traditions of their country and country of the language which is being studied; ability to integrate themselves into the modern cultural and economic environment;

- ability to collect, systematize and synthesize other cultural information of interest to students; the ability to represent one's home country and culture, role models and lifestyles in cross-cultural intercultural communication.

A competent foreign language teacher should be able to: comment on the content of culturally oriented vocabulary and phraseology in foreign and native languages; correctly use culturally oriented vocabulary in the language; to find sociocultural information in different types of authentic texts; create sociocultural portraits of communication participants / heroes of artistic texts; adequately interpret (understand) and respond to verbal and non-verbal behavior of representatives of other linguistic and cultural communities; to build foreign language communication in accordance with the norms of verbal and non-verbal communicative behavior adopted by a certain linguistic and cultural community.

The personality-semantic component of students' sociocultural competence is characterized by the degree of awareness of the personal and social significance of sociocultural competence; the ability to perceive "other" with positive emotions; an empathetic attitude towards representatives of other cultures; sociocultural observation; impartiality in the interpretation of sociocultural phenomena (Ryske, 2000: 11).

The selected criteria for the formation of sociocultural competence of students of the University of Humanities became the starting point for studying its level manifestations. The main criterion in the allocation of levels was the degree of formation of the structural leading components of sociocultural competence.

In order to determine the level of this competence which is already formed, we conducted a second-year student diagnosis of the Faculty of Foreign Languages, which contained the task of testing students' national knowledge and their communication skills in the field of 
intercultural communication. We have noted significant sociocultural mistakes made in performing the proposed tasks. The main mistakes were in the transmission of stereotypes of linguistic behavior in English. 46\% of graduates - future teacher-philologists had difficulty in correlating even well-known phenomena of another culture with similar phenomena of their native culture, in the context of intercultural communication. In this regard, it became necessary for students to develop skills to adequately interpret a foreign language reality in Ukrainian or English, that is, sociocultural competence.

In identifying the levels of development of students' sociocultural competence, we proceeded from the methodological position that the system in its development goes through a series of stages from the birth of individual elements, their grouping, through the integration of all elements into a single system to integrity, when the forces of self-motion are activated.

\section{The analysis of students' levels of sociocultural competence}

Therefore, taking as a basis the level of readiness for professional activity allocated to N. Sergeyev, we have defined three levels of becoming sociocultural competence of students (Sergeyev, 2004:14):

- low - the level of intuitive and active participant in intercultural communication;

- middle - the level of an informed person;

- high - the level of consciously-active participant of intercultural communication mediator of cultures.

Developing the idea of level changes of mental formations, S. Rubinstein wrote that "each link ... being qualitatively different from all others, is relatively whole so that its psychological characterization as some specific whole is possible. Any previous link is a preparatory stage for the next one; in the beginning, the forces and relationships that, when they lead, give rise to a new link in development are the subordinate motives" (Rubinstein, 1973: 423).

The first (low) level is the level of intuitively active participant in intercultural communication. To this level we refer students whose sociocultural knowledge is at the level of everyday consciousness, serving the vital needs of communicators. Students with this level of competence are perceived only on the outside of objective sociocultural conditions, without revealing their nature and patterns of development. Sociocultural perceptions of students of this level are characterized by limitations, when the phenomena of foreign language reality is simply stated. However, students assigned to this level of sociocultural competence have a sufficient level of knowledge about the culture of their native country and are able to speak about it in their native language. The students of this level group do not always know and adhere to the main features of formal and informal foreign language communication in oral and written language may admit sociolinguistic errors (cognitive component). Students who have been identified with a given level of sociocultural competence are not able to:

- distinguish cultural values by observing and interacting with carriers of other cultures;

- apply the knowledge outlined in the practice of communication in order to achieve mutual understanding based on the creation of common meaning;

- construct their own verbal and non-verbal behavior in accordance with the norms of the language culture being studied (activity-practical component).

The personality-semantic component was developed at the initial level: these students intuitively manage emotions and perceive the "other" as an equal partner, often not quite adapted to the phenomena of foreign language culture. For example, in a foreign language class, such students do not show activity and independence. 
The second level (middle) is the level of an informed person. Students in this level group are mostly familiar with the culture of their country and the foreign country which languages they are learning; find common and different in their historically formed cultural models of development; in oral and written communication, they know and adhere to the rules adopted in different spheres of communication, taking into account the different degree of formality; make minor sociolinguistic errors (cognitive component). Students in this level group are not always able to:

- distinguish cultural values by observing and interacting with carriers of other cultures;

- apply the above knowledge in the practice of communication in order to achieve mutual understanding based on the creation of common meaning;

- build their own verbal and non-verbal behavior in relation to the norms of the language culture being studied (activity-practical component). Students manage their emotions, perceive the "other" as an equal partner, tolerant and adapted to the phenomena of foreign-language culture at a level insufficient for the dialogue of cultures (personality-semantic component).

The third (high) level is the level of consciously-active participant of intercultural communication - mediator of cultures. Such students whose sociocultural competence is formed at this level are well aware of the world culture, able to analyze the experience of cultural development of different countries in the interaction of different cultures, and to trace its reflection in the language of this country. Students of this level group do not experience sociolinguistic and sociocultural difficulties in virtually any field of communication, given the norms of formal and informal communication in oral and written language (cognitive component). Activity-practical and personality-meaning components reach a high level of development.

The participants of intercultural communication with this level of development of sociocultural competence are characterized by emotional comfort, a sense of national identity, the opportunity to be themselves and to represent their own culture, the desire to continue communication, intercultural interaction.

\section{The results of diagnosing the levels of formation of the sociocultural competence of students of the Faculty of Foreign Languages}

The descriptions of each level of sociocultural competence development are relevant not only for the theoretical model, but also serve as a benchmark when comparing the characteristics of particular students to attribute them to one or another level of sociocultural competence development, as well as being criteria for the effectiveness of the whole process as a whole and every single stage of it.

The first level - the level of intuitively-active participant of intercultural communication - the formation of sociocultural competence is defined in the study as low. According to the results of the ascertaining stage of the experimental work, we assigned $64 \%$ of students of the second year of the Faculty of Foreign Languages to this level group.

Its peculiarities are well evident from the example of the monographic characteristic of the student Christina $K$. The level of communicative culture and sociocultural education of this student does not allow her to be an equal partner of intercultural communication on a foreign language in sociocultural, everyday, educational and professional spheres. She does not have the ethics of discussing on foreign language when discussing the culture, styles and lifestyles of the people of the language she is learning. The student does not know or adhere to the basic features of formal and informal communication in oral and written language, characteristic of English. Christina can make mistakes of a sociolinguistic nature. When organizing 
foreign-language intercultural communication in the context of modeling situations, she does not always use lexical units with national-cultural semantics; does not fully know the linguistic features of social groups, representatives of different generations, social groups. Christina does not have socioculturally-predicated scenarios, nationally specific behavior, using the communicative technique adopted in that culture.

However, generally speaking, Christine is able to: a) isolate cultural values in her native language by observing and interacting with speakers of other cultures; b) start, support and end a simple conversation on a familiar or interesting topic; c) distinguish between intonational models of foreign and native languages, but not able to recognize in the audio recordings sociocultural elements relating to models of behavior, rituals, formulas of politeness, to highlight in the text information of the cultural plan (sociocultural patterns of behavior, rituals).

The student manages emotions intuitively, not ready to perceive "other" as equal partner. The level of tolerance is low, which is manifested in the lack of adaptation to the phenomena of foreign language culture. In characterizing the overall formation of sociocultural competence at this level, it is necessary to note the weak development of all components. The students of this group do not have an attitude towards themselves as future mediators of cultures, do not express a clear desire for the establishment of a system of universal cultural values and the ability to carry out intercultural communication within the framework of "dialogue of cultures".

We consider the features of the next level of development of sociocultural competence, which we called average - the level of an informed personality. On the basis of the conducted diagnostic research, $25 \%$ of the second year students correspond to this level of sociocultural competence.

A typical representative of this level is a student, Yana $V$. She, mainly knows the culture of her country and foreign countries (Germany and England), often finds common and different in their historically formed cultural models of development; in oral and written communication knows and adheres to the rules adopted in different spheres of communication, taking into account the varying degrees of formality, but still the student assumes mistakes socio-linguistic nature. Yana, as a rule, is able to apply sociocultural knowledge in the practice of communication with native speakers of the first foreign language. She knows the specifics of verbal and non-verbal behavior in different situations of intercultural communication, but is not always able to identify and isolate information related to intercultural differences between her native and foreign languages. She is able to find examples to illustrate words, complex syntactic models, intercultural differences, but is not able to make comparative analyzes of source language (foreign language) and translation language (mother tongue) in terms of translation, similarity and differences in conceptual, lexical and grammatical aspects. The student may find in simple text the sociocultural norms of verbal and non-verbal behavior, as well as terminological correspondences in the language of translation, but does not take into account the possible intercultural differences in their semantics and the dependence of the translation of the term on the context. It converts the language structures required to transmit the original message in an adequate form, but cannot choose the optimal translation option in the case of partial differences in the amount of concepts in the source language and the language of translation.

The student possesses personal qualities that contribute to adequate communication with native speakers. She is emotionally endured, tolerant and loyal to the specific manifestations of the cultural traditions of foreign languages.

In general, students at this level show their own understanding of the sociocultural features of their own and foreign-language culture, which is expressed in the desire for dialogue of cultures through languages. 
The third level of sociocultural competence development was defined as high - the level of consciously-active participant of intercultural communication - mediator of cultures, to which $11 \%$ of students of the experimental group corresponded.

Student Olena $C$. knows the world culture well, knows how to analyze the cultural development experience of the languages spoken in the interaction of different cultures, as well as to trace its reflection in the language of one or another country, as she had experience in learning several foreign languages, studying at high school and different language courses. She has almost no difficulty in sociolinguistic and sociocultural character in the field of communication, takes into account the norms of formal and informal communication in oral and written language. Practical and practical and semantic components reach a high level of development. The student is able to clearly express her thoughts, while using understandable language recipients, recognizes different accents and styles in the language. Olena is able to highlight culturally significant linguistic units that need additional explanation in the language being taught, as well as to compare the linguistic organization of different types of discourse in both native and foreign languages. The student is able to distinguish explicit and hidden cultural information in the text, to find examples illustrating connotative coloring, style of language units, their connection with the country's culture. Using linguistic terms, Olena can explain the phonological, grammatical and semantic features of words or idioms, as well as their sociocultural component and pragmatic properties. When preparing various sociocultural projects, Olena is highly aware of the writers, cultural phenomena used in the quotations. She often cites examples that illustrate overt and hidden intercultural differences, and, where appropriate, take into account intercultural differences in the designation of an object, its features, actions, and transmissions of subject-object, cause-effect, and other relationships. Olena, who has a given level of development of sociocultural competence, is characterized by emotional comfort, a sense of national identity, the opportunity to be herself and represent her own culture, the desire to continue communication, intercultural interaction.

The theoretical model of diagnostics of the quality of formation of sociocultural competence of the students presented by us allows to organize pedagogical process in a certain system and for each student who is at the appropriate level of development of sociocultural competence, as well as to determine the most adequate pedagogical means. This allows teachers to concentrate their attention on the formation of individual structural components of students' sociocultural competence and to stimulate the manifestation and realization of criteria that temporarily prevent them from moving to the next level of development.

\section{Conclusions}

Thus, based on the above analysis, we can conclude that today foreign language training in the undergraduate system involves active intercultural communication in the framework of their professional activities. Accordingly, the involvement of social and cultural components while learning a foreign language and the organization of sociocultural activities at the Faculty of Foreign Languages are absolutely necessary to achieve the basic practical goal of developing the ability to communicate in the language which is being taught. From this consideration follows that the purpose of learning foreign languages, both in mastering them and in relation to their teaching, involves acquaintance with universal values, which promotes the education of students in the context of "dialogue of cultures".

The results of the experiment showed that these students had a lack of theoretical knowledge about the formation of sociocultural competence, as well as methods of practical 
implementation of modern technologies in the educational process of higher education institutions. Possession of sociocultural competence is the main feature of a successful and professional philologist.

Based on the results obtained, it should be noted that in view of the decent and comprehensive provision of sociocultural competence, students are active participants in the educational process, they have developed a stable positive attitude to the quality of foreign language training, which, in turn, promotes the implementation of general, educational and practical purposes.

\section{References}

Ageeva M. I., Klimova E. A. (2017). Diagnostika urovnya sformirovannosti sotsiokul'turnoy kompetentsii studentov fakul'teta inostrannykh yazykov TGPU im. L. N. Tolstogo // [Diagnostics of the level of formation of sociocultural competence of students of the faculty of foreign languages of TSPU named after L. N. Tolstoy]. Youth Scientific Forum: Humanities: electr. compilation by Proceedings of the XII International scientific and practical conference, No. 1 (40). Retrieved from: https://nauchforum.ru/archive/MNF_humanities/1(40).pdf (accessed 10 september 2020)

Babushkina L. E. (2012). Nekotorye osobennosti formirovaniya sotsiokul turnoy kompetentsii studentov pedvuza [Some features of the formation of sociocultural competence of pedagogical university students]. In the world of scientific discoveries, no. 9, pp. 11-28 [in Russian].

Deardorff D. (2006). Identification and assessment of intercultural competence as a student outcome of internationalization. The Journal of Studies in International Education, no. 10 (3), pp. 241-266. doi: 10.1177/1028315306287002. [in English].

Kniazian M. \& Mushynska N. (2019). The Formation of Translators' Research Competence at the Universities of Ukraine. The Journal of Teaching English for Specific and Academic Purposes, vol. 7, no. 1, pp. 85-94. doi: https://doi.org/10.22190/JTESAP1901085K [in English].

Kniazian M. \& Mushynska N. (2019). Social Innovations in the Professional Training of Managers under the Conditions of Knowledge Economy Development. Baltic Journal of Economic Studies. vol. 5, no. 2, pp. 137-143. doi: https://doi.org/10.30525/2256-0742/2019-5-2-137-143 [in English].

Kniazian M. (2020). et al. Organization of Research Work of Future Pedagogues in Higher Education Institutions: Experiential Learning Results. Revista Românească pentru Educaţie Multidimensională, vol. 12, no. 1, pp. 265-290. doi: https://doi:10.18662/rrem/213 [in English]. Kniazian M. \& Khromchenko O. (2019). The ESP Lecturers'Self-Development Competence in Higher Educational Context. The Journal of Teaching English for Specific and Academic Purposes, vol. 7, no. 3, pp. 385-393. doi: https://doi.org/10.22190/JTESAP1903385K [in English]. Kosinskaya E. V. (2015). Rol' motivatsii v izuchenii inostrannogo yazyka [The role of motivation in the study of a foreign language]. Territory of science, no 5, pp.33-37 [in Russian].

Khutorskoy A. V. (2003). Klyuchevye kompetencii kak komponent lichnostno orientirovannogo obrazovaniya [Key competencies as component of personality-oriented education]. Public education, no. 2. pp. 58-64. [in Russian].

Latukhina M. V. (2014). Ponyatie sotsiokul'turnoy kompetentsii v obuchenii angliyskomu yazyku [The concept of sociocultural competence in teaching English]. Young scientist, no. 20, pp. 725-727 [in Russian].

Posel'skaya N. V. (2012). Osnovy formirovaniya sotsiokul'turnoy kompetentsii studentov pri obuchenii inostrannomu yazyku $v$ neyazykovom vuze [Fundamentals of the formation of 
sociocultural competence of students in teaching a foreign language in a non-linguistic university]. Siberian Pedagogical Journal, no. 4, pp. 268-273 [in Russian].

Riske I. E. (2000). Formirovanie sotsiokul'turnoy kompetentsii u uchashchikhsya starshey stupeni obucheniya na materi ale angloyazychnoy poezii: avtoref. dis...kand.ped.nauk (13.00.02) [The formation of sociocultural competence among senior-level students in the material of English poetry: Candidate's Thesis (13.00.02)]. RGPU im. A.I. Gertsena SPb., p. 16 [in Russian].

Rubinshteyn S. L. (1989). Osnovy obshchey psikhologii [Fundamentals of General Psychology]. M.: Pedagogika, p. 485 [in Russian].

Safonova V. V. (1991). Sotsiokul'turnyy podkhod k obucheniyu inostrannym yazykam [Sociocultural approach to teaching foreign languages]. M.: Vyssh. shk., p. 305 [in Russian].

Sergeev N. K. (2004). Tselostnyy podkhod v sisteme metodologicheskikh regulyativov pedagogicheskogo issledovaniya [A holistic approach in the system of methodological regulations of pedagogical research]. Ser. Pedagogical sciences, no. 1(06), pp. 12-16 [in Russian].

Sysoev P. V. (2001). Yazyk i kul'tura: v poiskakh novogo napravleniya v prepodavanii kul'tury strany izuchaemogo yazyka [Language and culture: in search of a new direction in teaching the culture of the country of the language being studied]. Foreign languages at school, no. 4, pp. 12-18 [in Russian].

Filosofskiy entsiklopedicheskiy slovar' (2003) [Philosophical Encyclopedic Dictionary]. M.: INFRA-M., p. 226 [in Russian]. 